\title{
ENDOGENICZNOŚĆ W ROZWOJU REGIONÓW/ EUROREGIONÓW W ASPEKCIE EUROPEJSKICH WYZWAŃ SMART SPECIALISATION
}

\begin{abstract}
Streszczenie
W opracowaniu skoncentrowano się głównie na zagadnieniach związanych z potencjałem wewnętrznym regionów i możliwościami jego zastosowania w inteligentnej specjalizacji, która stanowi europejskie wyzwanie rozwojowe, bowiem wchodzi w zakres strategii rozwojowej „Europa 2020” i ma na celu rozpoznanie zasobów regionu. Staje się to zwłaszcza istotne w przypadku euroregionów, które z jednej strony, sa peryferyjne ze wszystkimi tego konsekwencjami, ale z drugiej, doskonale przygotowane do rozpoznania swoich wewnętrznych możliwości i wykorzystania endogenicznych teorii rozwojowych w budowaniu własnych strategii rozwojowych.
\end{abstract}

Słowa kluczowe: region/euroregion, potencjał endogeniczny, inteligentna specjalizacja, „Strategia Europa 2020"

\section{ENDOGENOUSNESS IN DEVELOPMENT OF REGIONS/EUROREGIONS AND CHALLENGES OF EUROPEAN SMART SPECIALISATION: SELECTED ISSUES}

\section{Summary}

The study is focused mainly on issues associated with the internal potential of regions and the possibilities of its exploitation for intelligent specialisation, which has become a challenge for European development. Intelligent specialisation falls within the scope of the Europe 2020 strategy and is aimed at the recognition of regional resources. It is becoming especially essential in the case of Euroregions which, on the one hand, are peripheral with all the consequences of the fact but, on the other hand, are perfectly capable of identifying their internal possibilities and using endogenous developmental theories for building their developmental strategies.

Key words: region/euroregion, endogenous potential, intelligent specialisation, Strategy Europe 2020

\section{Wstęp}

Regiony i polityka regionalna zawsze stanowiły ważne zagadnienie w funkcjonowaniu Wspólnot Europejskich (WE), a dziś Unii Europejskiej (UE). W zależności od wyzwań strategicznych i horyzontalnych, które ugrupowanie stawiało sobie za cel i prio-

\footnotetext{
${ }^{1}$ dr hab. Marianna Greta, prof. PŁ - Wydział Organizacji i Zarządzania, Politechnika Łódzka; e-mail: marianna.greta@p.lodz.pl.
} 
rytet w danym okresie, zwracano uwage na różne aspekty tejże polityki, co znajdowało wyraz w formułowaniu i reformowaniu celów polityki regionalnej. Obecnie, kiedy Stary Kontynent - według niektórych opinii i stawianych tez - staje na rozdrożu, a Europie groziłaby wizja Europy tzw. wielu prędkości, można byłoby sądzić, iż jej pełne urzeczywistnienie oznaczałoby sprzeniewierzenie się fundamentalnym wartościom integracji europejskiej. Regiony wraz z wpisaną w swoją filozofię subsydialnością oraz eksternalizacją unijnej polityki regionalnej/spójności do polityk narodowych w „odkrycie” i urzeczywistnienie endogeniczności regionów mogą okazać się skutecznym narzędziem w wykorzystaniu możliwości rozwojowych, a tym samym realizacji „Strategii Europa 2020". Słowem, unijna polityka regionalna i pomoc w jej ramach ułatwia dotarcie do potencjału wewnątrzunijnego w kierunku wykorzystania go do inteligentnej specjalizacji, a tego właśnie dotyczy „Strategia Europa 2020”. Ponadto, należy podkreślić, iż regionami szczególnie podatnymi na wykorzystanie potencjału endogenicznego przy pomocy unijnej polityki regionalnej/spójności są euroregiony. Peryferyjność i zaniedbania gospodarcze pozbawiły obszary przygraniczne zainteresowania nimi. Jednakże euroregionalizacja była i jest czynnikiem sprawczym odkrycia na nowo obszarów przygranicznych i ich endogenicznego potencjału, a także jego wykorzystania w kierunku inteligentnej specjalizacji.

Celem opracowania jest udokumentowanie, iż potencjał wewnattrzregionalny i endogeniczne teorie rozwoju regionalnego mają zasadnicze znaczenie w realizacji inteligentnego rozwoju, a euroregiony są szczególnym przykładem powyższego twierdzenia. W związku z tym, wybrano do opisu kilka zagadnień, w tym m.in.:

- region, rozwój regionalny, czynniki rozwoju regionalnego i euroregionalnego;

- wybrane teorie rozwoju regionalnego, ukierunkowanie na potencjał endogeniczny;

- $\quad$ wykorzystanie endogenicznego potencjału do inteligentnej specjalizacji w kontekście znaczenia euroregionów w rozwoju regionalnym.

Oczywiście, zgodnie z tematem, zostaną tylko zasygnalizowane i wskazane wybrane zagadnienia, gdyż obejmuja one zbyt szeroki zakres, aby je w niniejszym artykule przedstawić w całości. Natomiast ich określenie może być impulsem do dalszych badań i analiz naukowych.

\section{Region/euroregion i rozwój regionalny. Czynniki rozwoju regionalnego}

Definicję regionów uzależnia się m.in. od dyscypliny naukowej, która determinuje podejście: ekonomiczne, socjo-kulturowe, etniczne, prawne czy polityczne. Jednak, niezależnie od powyższego ukierunkowania, każdy region (z łac. regio - okolica, obszar, teren) jest jednostką funkcjonalną, wyznaczoną przez czynniki: geograficzne, administracyjne, gospodarcze, społeczno-kulturowe bądź też psychologiczne, które są ze sobą ściśle powiązane i warunkują się nawzajem [Greta, 2003, s. 28 i dalsze]. Wydaje się, że, wyżej wymieniona, definicja godzi różne podejścia, wymieniając szereg cech, które „są własnością” każdego regionu, a jego znaczenie jest istotne. To znaczenie, które powoduje zainteresowanie regionem, tak w świetle teorii, jak i praktyki, wynika z wielu 
powodów. W Unii Europejskiej region jest fundamentem integracji przebiegającej na trzech płaszczyznach: region $\rightarrow$ gospodarka narodowa $\rightarrow$ ugrupowanie ponadnarodowe. Są także bardziej ogólne zakresy znaczeniowe nadające wartość regionom, np.:

- regiony stanowia główne narzędzie rozpoznawania przestrzeni ekonomicznej i regionalnych zróżnicowań;

- $\quad$ regiony sa podstawą do badania większych obszarów regionalnych, a przez to umożliwiaja zdobywanie informacji celem rozszerzenia jej i uogólniania na większe „zbiory” regionalne;

- $\quad$ rozpoznanie cech jednego regionu może pozwolić na ich identyfikację $\mathrm{w}$ innym regionie, zwłaszcza gdy sa to regiony o znaczących podobieństwach;

- regiony sa podstawa do modyfikowania sposobów rozwoju, szczególnie tam, gdzie rozwój regionalny wykazuje pewną zbieżność z rozwojem gospodarki narodowej jako całości albo zbyt duży stopień rozbieżności [Domański, 2002, s. 110-111].

Zatem, badania nad regionem i jego rozwojem sa potrzebne tak z ekonomicznego, jak i społecznego punktu widzenia. Nabierają one szczególnego znaczenia, gdy zostana poszerzone o kontekst integracyjny, przede wszystkim w związku z upodmiotowieniem społeczności regionów i wyzwaniami unii gospodarczej, wymagającej spójności: gospodarczej, społecznej i terytorialnej.

Z regionem ściśle łączy się pojęcie rozwoju regionu i rozwoju regionalnego. Rozwój regionu dotyczy rozwoju tkwiących w nim zasobów w kierunku wzbogacania jego wewnętrznej struktury lub relacji zachodzących między tymi elementami, zaś rozwój regionalny to rozwój krajowy w jego podziale na jednostki terytorialne - regiony, które stanowia wypadkową rozwoju regionów.

Z kolei, euroregion jest specyficznym rodzajem regionu, o czym decyduje m.in. jego peryferyjne, przygraniczne położenie oraz więzi transgraniczne łączące go z regionem „zza miedzy”, czyli granicy państwowej. Jeśli odnieść do niego, przyjętą tu, uniwersalną definicję regionu, to należy podkreślić występowanie w euroregionie: szczególnych więzi społeczno-kulturowych, poczucia wspólnoty i znajomości, jak również świadomości wewnątrzregionalnego potencjału.

Problem, zwiazany z czynnikami rozwoju regionalnego, jest obecnie rozbudowanym zagadnieniem stanowiącym platformę poszukiwań tych najskuteczniejszych, chociaż punkt wyjścia tworzą: kapitał rzeczowy i zasoby ludzkie oraz ziemia. To z nich wyrastają wszelkiego rodzaju kombinacje czynników produkcji, które potem wykorzystuje się do budowy teorii i strategii rozwojowych. Poniżej skonstruowano tabelę, w której z jednej strony, zebrano czynniki rozwoju regionalnego, na które wskazuje literatura, a z drugiej - te, które uwzględniają raporty kohezyjne Unii Europejskiej. 


\section{Czynniki rozwoju regionalnego}

TABELA 1.

\begin{tabular}{|c|c|}
\hline$\ldots$ & $\begin{array}{c}\text {... w praktyce Unii Europejskiej, } \\
\text { uwzględniane w raportach }\end{array}$ \\
\hline 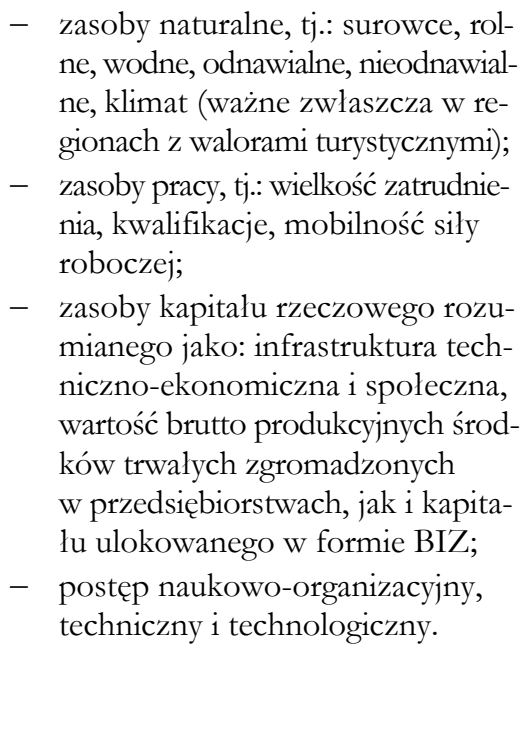 & $\begin{array}{l}\text { - } \text { nowoczesna struktura działalności gospodar- } \\
\text { czej charakteryzowana sektorową struktura } \\
\text { zatrudnienia w przekroju: rolnictwo - prze- } \\
\text { mysł przetwórczy - budownictwo - usługi } \\
\text { rynkowe - usługi nierynkowe i udziałem sek- } \\
\text { torów w tworzeniu PKB; } \\
\text { - } \text { intensywność działalności w sferze innowa- } \\
\text { cji produktowych i procesowych; } \\
\text { - dostępność regionów do rynków zbytu, dete- } \\
\text { rminowana łatwością transportu dóbr i usług } \\
\text { wytwarzanych w regionie na rynki spoza } \\
\text { regionu; } \\
\text { - kwalifikacje siły roboczej odzwierciedlające } \\
\text { jakość zasobów ludzkich, zależnych m.in. od: } \\
\text { poziomu wykształcenia, poziomu rozwoju } \\
\text { ochrony zdrowia; } \\
\text { tendencje demograficzne i przepływy migra- } \\
\text { cyjne. }\end{array}$ \\
\hline
\end{tabular}

Źródło: opracowanie własne na podstawie: [Kudłacz, 1999, s. 15 i dalsze; Pietrzyk, 2001, s. 32 i dalsze; Molle, 2011, s. 71-71; Barea, 2011, s. 17 i dalsze; Okresowe Raporty...].

W każdej praktycznie analizie są uwzględniane czynniki odnoszące się do infrastruktury czy zasobów ludzkich i konfiguracje, które dalej dają się uporządkować w tradycyjne (ilościowe) oraz nowoczesne (jakościowe). Obecnie do głównych czynników rozwoju regionalnego zalicza się mobilizowanie endogenicznego potencjału rozwojowego tkwiącego w regionach, a nie bezwzględnego ich poziomu. Prowadzi to bowiem do pobudzania rozwoju lokalnego, oznaczającego „oddolny” (bottom-up) sposób generowania dynamiki rozwoju, oraz podejmowania decyzji przez samorządy bądź prywatne podmioty ekonomiczne. Do lokalnych czynników rozwoju regionalnego zalicza się:

- przywództwo mobilizujące decydentów i członków zbiorowości lokalnych;

- $\quad$ audyt strategiczny, czyli kierunkowe określenie zasad i celów rozwoju regionalnego;

- $\quad$ współudział lokalnych społeczności w życiu społeczno-gospodarczym swoich obszarów;

- tożsamość kulturowa, dziedzictwo, poczucie wspólnoty i więzi oraz strukturę społeczno-polityczną regionu;

- $\quad$ współpracę funkcjonujących w regionie podmiotów oraz elastyczność prowadzonych działań względem ewoluującego otoczenia i zmian strukturalnych [Pietrzyk, 2001, s. 32 i dalsze]. 
Gdyby powyższe lokalne czynniki uwzględnić w euroregionie, to okaże się, iż działają tu one ze wzmożoną siła, gdyż poczucie lokalności, więzi lokalnych i współdziałanie społeczności lokalnych są wpisane w filozofię „misji” euroregionu.

\section{Endogeniczność - od teorii do strategii}

Dysproporcje w rozwoju regionalnym są powszechnościa a determinowane są m.in.:

- $\quad$ procesami związanymi z podziałem pracy w społeczeństwie uprzemysłowionym;

- $\quad$ coraz krótszymi cyklami rozwoju innowacji;

- globalizacja i cyfryzacją

- nowymi standardami w kwalifikacjach i umiejętnościach;

- różnymi endogenicznymi potencjałami wyjściowymi regionów.

Bardzo istotny element stanowią zróżnicowania i bogactwa zarazem w zawartości endogenicznej, która daje możliwości wykorzystania korzyści komparatywnych w konkurencji wobec innych regionów przez koncentrowanie się na specyficznych i naturalnych korzyściach wynikających z:

- położenia geograficznego;

- $\quad$ tradycji handlowych i przemysłowych;

- $\quad$ szczególnych kwalifikacji zasobów ludzkich;

- $\quad$ specyficznych celów kulturowych i politycznych występujacych w regionie.

W odniesieniu do euroregionów wszystkie te elementy zasobności endogenicznej także przemawiają na ich korzyść, jeśli pominać peryferyjność położenia geograficznego, którą euroregionalizacja skutecznie przezwycięża.

Z kolei, potencjał endogeniczny inicjuje: procesy wzrostu wewnątrzregionalnego, rozwój wysiłków przystosowanych do: wymogów regionalnych, społecznych i ekologicznych, zdecentralizowany system podejmowania decyzji oraz procesy rozwoju zrównoważonego. W tabeli 2. opisano wybrane teorie rozwoju regionalnego, wskazujące na potrzebę wykorzystania endogeniczności.

Opisane w tabeli 2. teorie wskazują, przy uwzględnieniu endogeniczności, na takie elementy pozytywne, jak:

- bliskość produkcji i konsumpcji;

- $\quad$ znajomość wyposażenia w czynniki produkcji i decydowanie o ich przemieszczeniu dla wyeksponowania mocnych stron regionu;

- zróżnicowanie determinantów rozwoju. 
TABELA 2. Wybrane teorie rozwoju regionalnego wskazujące na wagę endogeniczności

\begin{tabular}{|c|c|}
\hline $\begin{array}{c}\text { Rodzaje teorii } \\
\text { rozwoju regional- } \\
\text { nego }\end{array}$ & Główne teorie rozwoju regionalnego \\
\hline Teoria lokalizacji & $\begin{array}{l}\text { Wyjaśnia przestrzenne zróżnicowanie rozwoju przez podejmo- } \\
\text { wanie działalności gospodarczej w określonych miejscach w przes- } \\
\text { trzeni. Teoria lokalizacji struktur została wyjaśniona na podstawie } \\
\text { tzw. renty położenia, która jest tym wyższa, im miejsce produk- } \\
\text { cji znajduje się bliżej miejsca konsumpcji. }\end{array}$ \\
\hline $\begin{array}{l}\text { Teorie: klasyczna } \\
\text { i neoklasyczna }\end{array}$ & $\begin{array}{l}\text { Teorie klasyczne biorą swój początek od A. Smitha. Zakładają one, } \\
\text { iż na rynku panuje konkurencja doskonała, a praca i kapitał są czyn- } \\
\text { nikami mobilnymi, których wykorzystanie do produkcji tych sa- } \\
\text { mych dóbr daje stałe zyski. W odniesieniu do teorii wzrostu re- } \\
\text { gionalnego oznacza to, że przez mechanizm cenowy czynniki pro- } \\
\text { dukcji przemieszczają się do miejsc, w których przynoszą najwyższą } \\
\text { użyteczność krańcową. W tej grupie teorii jest teoria kosztów } \\
\text { komparatywnych D. Ricardo, zakładająca wzrost dobrobytu krajów } \\
\text { i regionów dzięki specjalizacji w produkcji określonych dóbr oraz } \\
\text { w ich wymianie. Na podstawie powyższej teorii powstała neokla- } \\
\text { syczna teoria obfitości zasobów Heckschera-Ohlina. }\end{array}$ \\
\hline $\begin{array}{l}\text { Teorie polaryza- } \\
\text { cji: } \\
\text { - bieguny wzrostu; } \\
\text { - centrum - pery- } \\
\text { ferie }\end{array}$ & $\begin{array}{l}\text { Ich wspólnym elementem jest zgodność, iż istniejące różnice } \\
\text { przestrzenne są pogłębiane przez cyklicznie skumulowane pro- } \\
\text { cesy rozwojowe. W teoriach tych zakłada się: zróżnicowanie prze- } \\
\text { strzeni gospodarczej dotyczace determinantów rozwoju, tj.: struktu- } \\
\text { ry branżowej oraz konsumpcji i inwestycji; częściową niemobil- } \\
\text { ność determinantów rozwoju; zależność regionów w procesie } \\
\text { rozwoju; występowanie struktur rynkowych w postaci monopoli } \\
\text { i oligopoli. }\end{array}$ \\
\hline $\begin{array}{l}\text { Nowa geografia } \\
\text { ekonomiczna }\end{array}$ & $\begin{array}{l}\text { Twórca tej teorii jest m.in. P. R. Krugman, a powstałej w wyniku } \\
\text { dyskusji i właczenia teorii geografii przestrzennej do głównego nur- } \\
\text { tu ekonomii. Według tej teorii, rozwój regionu jest wypadkowa } \\
\text { sił odśrodkowych odpowiedzialnych za ograniczanie aglomeracji } \\
\text { lub ich rozpad oraz sił dośrodkowych determinujących przycią- } \\
\text { ganie działalności gospodarczej do aglomeracji. }\end{array}$ \\
\hline $\begin{array}{l}\text { Współczesne teo- } \\
\text { rie rozwoju regio- } \\
\text { nalnego }\end{array}$ & $\begin{array}{l}\text { Ich wspólną cechą jest postrzeganie terytorium jako czynnika wzro- } \\
\text { stu endogenicznego o określonych kombinacjach zasobów i cech } \\
\text { danego regionu. Nawiązują one do teorii lokalizacji i w związku } \\
\text { z tym mobilizowania endogenicznych czynników rozwoju regio- } \\
\text { nalnego. }\end{array}$ \\
\hline
\end{tabular}

Źródło: opracowanie własne na podstawie: [Bartkowiak, 2003, s. 33 i dalsze; Krugman, 1995, s. 196-198; Krugman, 1991, s. 179 i dalsze; Nowińska-Laźniewska, 2004, s. 41].

Rozpoznanie możliwości endogenicznych pozwala przede wszystkim na właściwe przyjęcie zewnętrznych stymulatorów rozwojowych, które, występując m.in. w postaci unijnej pomocy strukturalnej, stały się powszechne wraz z polskim członkow- 
stwem w Unii Europejskiej. Natomiast aspekt terytorialny, który jest podstawą wzrostu endogenicznego o określonych kombinacjach zasobów i cech danego regionu, w dobie tworzenia wiedzy i cyfryzacji, także ma znaczenie kluczowe. Rezultatem ponownego zainteresowania kwestią obszaru i lokalizacji w rozwoju stały się nowe teorie rozwoju regionalnego: koncepcje sieci, grona, regionalne systemy innowacji, regiony uczące się [Florida, 2005, s. 528]. Skupienie uwagi na potencjale endogenicznym i rozpoznanie regionu daje możliwości opracowania mocnych i słabych stron regionu, których zestawienie jest sposobnościa opracowania strategii rozwojowej, by ją wykorzystać w praktyce. O strategiach rozwojowych przy uwzględnieniu mocnych i słabych stron regionu informuje tabela 3 .

TABELA 3.

\section{Strategie rozwojowe, konstruowane $z$ uwzględnieniem mocnych i słabych stron $\mathrm{w}$ regionie}

\begin{tabular}{|l|c|l|}
\hline Lp. & $\begin{array}{c}\text { Strategie - } \\
\text { rodzaje }\end{array}$ & \multicolumn{1}{c|}{ Opis istoty danej strategii rozwojowej } \\
\hline 1. & $\begin{array}{c}\text { Agresywna } \\
\text { (maxi - maxi) }\end{array}$ & $\begin{array}{l}\text { Charakteryzuje obszary, gdzie przeważają ich mocne strony } \\
\text { oraz szanse w ich otoczeniu. Jest to strategia silnej ekspansji } \\
\text { i zdywersyfikowanego rozwoju. }\end{array}$ \\
\hline 2. & $\begin{array}{c}\text { Konserwatywna } \\
\text { (maxi - mini) }\end{array}$ & $\begin{array}{l}\text { Bazuje na dużym potencjale wewnętrznym, ale musi pró- } \\
\text { bować przezwyciężać zagrożenia płynące z zewnętrz. }\end{array}$ \\
\hline 3. & $\begin{array}{c}\text { Konkurencyjna } \\
\text { (mini - maxi) }\end{array}$ & $\begin{array}{l}\text { Określa regiony, które maja przewagę słabych stron nad } \\
\text { mocnymi, ale sprzyja im układ warunków zewnętrznych. }\end{array}$ \\
\hline 4. & $\begin{array}{l}\text { Defensywna } \\
\text { (mini - mini) }\end{array}$ & $\begin{array}{l}\text { Cechuje regiony, które mają mniej szans rozwojowych ani- } \\
\text { żeli regiony wyróżniające się pozostałymi trzema typami } \\
\text { strategii. Obszary te istnieja w mniej przychylnym otocze- } \\
\text { niu, a ich potencjał rozwojowy jest słabszy. }\end{array}$ \\
\hline 5. & Mieszana & $\begin{array}{l}\text { Dla regionów, które nie mają wyraźnych słabych i mocnych } \\
\text { stron. }\end{array}$ \\
\hline
\end{tabular}

Źródło: opracowanie własne na podstawie: [Dahlstrom, Ekins, dokument elektroniczny, tryb dostępu: www.srdtools.info, data wejścia: 24.04.2013; dokument elektroniczny, tryb dostępu: www.karpacki.pl, data wejścia: 24.04.2013].

W przypadku tylko przewagi mocnych stron jest możliwa strategia agresywna, czyli ofensywna, wykorzystująca ową wewnętrzną potęgę gminy/obszaru w odniesieniu do zewnętrznych szans, jakie stwarza otoczenie rynkowe i pozarynkowe. Konserwatywna strategia rozwojowa jest charakterystyczna i właściwa dla regionów bazujących zwłaszcza na potencjale endogenicznym, ale musi się liczyć z przezwyciężaniem zagrożeń zewnętrznych. Zastosowanie praktyczne tych strategii, poprzedzone analizą SWOT (tj. słabych i mocnych stron), przyjęto w ramach rozwoju Euroregionu Karpackiego na południowo-wschodnim pograniczu Polski, w transgranicznym partnerstwie ze: Słowacja, Wegrami, Rumunią i Ukrainą. Strategia, opisywana w tabeli 3., była realizowana w, wyżej wymienionym, euroregionie w latach 2008-2010 w następującym układzie: 


\section{- Types of development strategies (AHP method);}

- Evaluation of development strategy of regions using analytic hierarchy process.

Wyraźna strategia agresywna charakteryzowała okręg Rumunki - Nord-Vest, który wykazywał przewage mocnych stron oraz szans w jego otoczeniu. Na pograniczu strategii agresywnej i konserwatywnej znalazło się Vychodne Slovensko, które bazowało na swoim dużym potencjale wewnętrznym. Strategię agresywną w 2008 roku miał także rumuński okręg Centru, jednak w następnych latach przybrała ona charakter mieszany, gdyż zmniejszyły się jego szanse w otoczeniu. Strategia mieszana cechowała także inny okręg rumuński - Nord-Est, który nie miał wyraźnych mocnych lub słabych stron. Z kolei, strategia konkurencyjna była reprezentowana przez trzy obwody ukraińskie: czerniowiecki, iwanofrankowski i lwowski, w których słabe strony przeważały nad mocnymi, ale za to sprzyjał im układ warunków zewnętrznych. Od 2009 roku obwód lwowski znamionowała strategia mieszana. Natomiast okręgi węgierskie reprezentowały strategię konserwatywną, która wykorzystuje duży potencjał wewnętrzny, lecz w ciągu okresu objętego analizą zmniejszał się on z roku na rok. Jednocześnie zmniejszały się zagrożenia płynące z zewnątrz. Tę samą strategię odzwierciedlało również województwo podkarpackie, jednak w porównaniu z okręgami węgierskimi miało więcej mocnych stron i zdecydowanie mniej zagrożeń zewnętrznych. Tymczasem obwód zakarpacki, który znajdował się w mniej przychylnym otoczeniu i jego potencjał rozwojowy był słabszy, cechowała w analizowanym okresie strategia defensywna [Dokument elektroniczny, tryb dostępu: http:/ / esw-tur.eu/, data wejścia: 24.04.2013; dokument elektroniczny, tryb dostępu: http://www.karpacki.pl/stowarzyszenie-karpaty/projekty-wlasne/polonia-ukrainatranscarpathia-nowe-otwarcie, data wejścia: 24.04.2013]. Podsumowując, można stwierdzić, że regiony, w których przeważały słabe strony lub zagrożenia, w ciągu analizowanego okresu poprawiały swoją sytuację w tym zakresie.

Wykorzystana wiedza, płynąca z teorii rozwojowych i zastosowana w scenariuszach strategicznych, pozwala na opracowanie jeszcze szerszych i bardziej dalekosiężnych przedsięwzięć regionalnych w postaci koncepcji rozwoju regionalnego, co przedstawia schemat 1.

Czytając ów schemat, należy podkreślić, iż na koncepcje rozwoju regionalnego składają się różne etapy (analiza, system celów, strategia, zasoby i organizacja), wśród których istotne miejsce zajmuje strategia. Z kolei, każdy etap zawiera pewne kroki, w tym na etapie strategii występują m.in. (jako kroki) scenariusze lub strategie alternatywne, co uwzględnia przykładowo tabela 3. W ten sposób można prześledzić wzajemne powiązania i współzależności między omawianymi w opracowaniu zagadnieniami. 
SCHEMAT 1.

Koncepcje rozwoju regionalnego - etapy i kroki

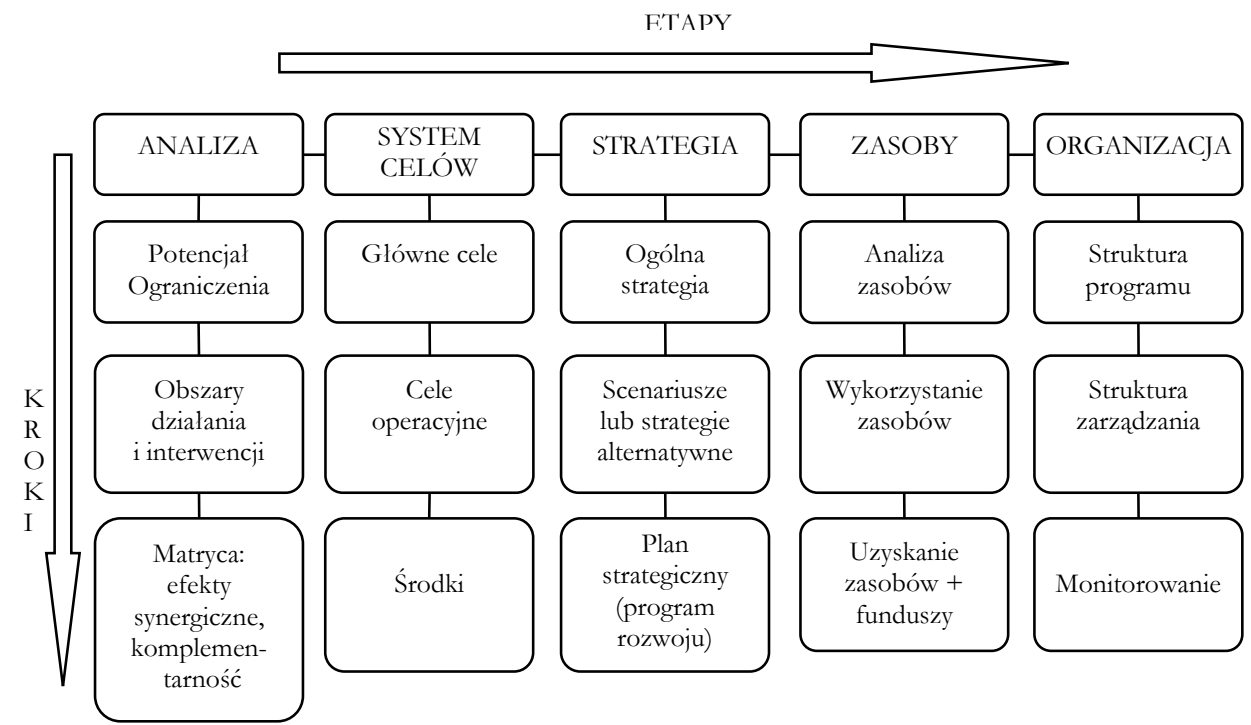

Źródło: opracowanie własne na podstawie: [Regionomica Europe Consulting - Regional Affairs and Business Consultants Dusseldorf/Berlin].

\section{Unia innowacji - smart specialisation - wyzwania europejskie}

Zagadnienia wyszczególnione w tytule fragmentu opracowania są ze sobą ściśle powiązane. Bowiem program „Unia Innowacji”, który służy osiaganiu inteligentnej specjalizacji, jest „wykonawcą” „Strategii Europa 2020”, w której są zawarte cele rozwojowe Unii Europejskiej, stanowiące wyzwania europejskie. Łańcuch owych zależności można zobrazować, posługując się poniższym schematem.

Polityka regionalna Unii Europejskiej, która obecnie jest realizowana jako polityka spójności, czyli wyraźnie ukierunkowana na pomoc regionom w wyrównywaniu różnic regionalnych, aby dalej stworzyć przesłanki w zdobywaniu przewag konkurencyjnych w regionach, wyznaczyła kierunek i kształt „Strategii, Europa 2020”. Strategia ta jest realizowana dzięki przyjęciu programów rozwojowych w ramach: wzrostu inteligentnego, zrównoważonego i wkluczenia społecznego. W obszarze zainteresowań w niniejszym opracowaniu pozostaje wzrost inteligentny, którego założenia wypełnia inteligentna specjalizacja. Polega ona na poszukaniu nowych kierunków rozwoju dla regionów, a nie popularyzowaniu tego, co robią inni poprzez wykorzystanie potencjału endogenicznego. Jest ona skierowana nie tylko do regionów liderów technologicznych, ale także do regionów, które posiadają potencjał nie wykorzystany i stanowia peryferia rozwojowe. $\mathrm{Na}$ rzecz inteligentnej specjalizacji sa realizowane unijne programy, jak również są opracowywane Strategie Innowacji 
Krajowych/Regionalnych (Strategia R/S3), które mają na celu wprowadzenie następujących założeń:

- wsparcie kluczowych inwestycji w wiedzę;

- wsparcie innowacji technologicznych i ich implementacji oraz stymulowanie inwestycji w sektorze prywatnym;

- wykorzystanie wewnattrzregionalnego potencjału przy wykorzystaniu mocnych stron i przewagi konkurencyjnej regionu;

- zachęcanie i zaangażowanie partnerów współpracy do innowacji i eksperymentów;

- $\quad$ uczynienie z innowacji priorytetu w każdym regionie [Komisja Europejska ..., dokument elektroniczny, tryb dostępu: www.ec.europa.eu, data wejścia: 7.10.2012].

SCHEMAT 2.

\section{Lańcuch zależności - Unia Europejka - Smart specialisation - „Unia Innowacji"}

UNIA EUROPEJSKA

i jej wyzwania rozwojowe prowadzace w ogólnym wymiarze do konkurencji na rynku globalnym
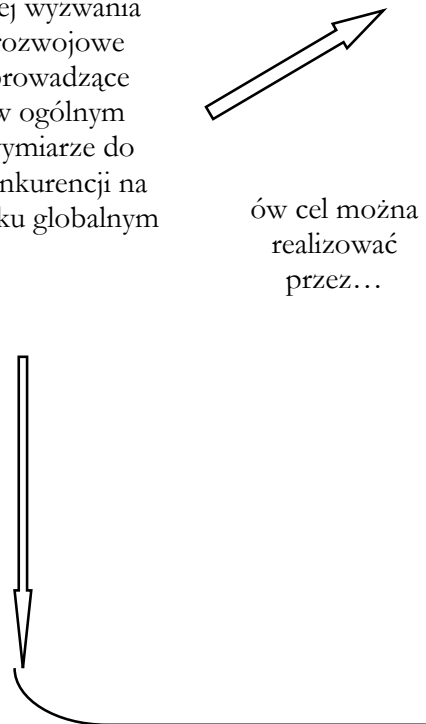

Są podstawą unijnej polityki regionalnej/spójności
SMART SPECIALISATION

czyli optymalne wykorzystanie wewnętrznego potencjału rozwojowego stosownie do specyficznych i unikatowych możliwości rozwojowych

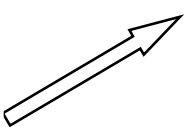

cel inteligentnej specjalizacji można osiagnać
„UNIA INNOWACJI"

program w ,Strategii Europa 2020" służący wzrostowi inteligentnemu m.in. przez inwestycje w nowe technologie i szeroko pojęte innowacje

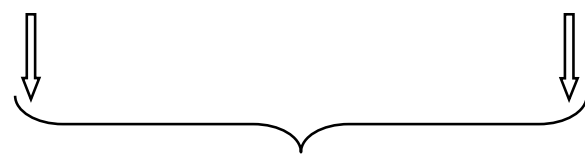

Smart Specialisation + „Unia Innowacji”

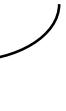

Źródło: opracowanie własne. 
Stopniowa, lecz konsekwentna realizacja tych założeń, których kumulacja przypada na nowa politykę regionalna/spójności, ma i powinna doprowadzić do zrealizowania wyzwań europejskich dotyczących m.in.:

- budowy gospodarki opartej na wiedzy;

- poprawy wspólpracy ośrodków badawczo-rozwojowych z biznesem;

- $\quad$ wsparcia rozwoju klastrów i sektora MSP.

Unia Europejska przywiązuje dużą wagę i łączy przyszłość z tymi wyzwaniami, a tym samym szansami konkurencyjności na rynku globalnym. W związku z powyższym, Komisja Europejska powołała w połowie 2011 roku specjalna platformę zwiazzana z inteligentna specjalizacja, tj. Smart Specialisation Platform, w celu popierania państw członkowskich i ich regionów w budowaniu strategii inteligentnej przez:

- udostępnianie wytycznych i innych dokumentów;

- upowszechnianie dobrych praktyk;

- $\quad$ organizowanie konferencji i sympozjów, kongresów odnoszących się do tej strategii;

- pobudzanie i ułatwianie możliwości realizacji własnych, krajowych pomysłów w, wyżej wymienionym, zakresie.

\section{Podsumowanie}

Strategia rozwojowa, przyjęta dla zjednoczonej Europy jako „Strategia Europa 2020", postawiła wymagania i wyzwania przed państwami i regionami. Wśród nich ważne miejsce przypadło inteligentnej specjalizacji, która zwraca się głównie ku endogeniczności regionów. W związku z powyższym, tak istotnym elementem realizacyjnym „Strategii Europa 2020” stały się krajowe strategie rozwojowe krajów członkowskich do 2020 roku. Wskazują one na strategiczne zadania krajów członkowskich, których podjęcie jest niezbędne, aby wzmocnić procesy rozwojowe zarówno w tych krajach, jak i w Unii Europejskiej, jako ugrupowaniu integracyjnym. Zadania te obejmują m.in. następujące obszary strategiczne:

- $\quad$ sprawne i efektywne państwo;

- konkurencyjna gospodarkę;

- spójność społeczną i terytorialna.

$\mathrm{Na}$ szczeblu unijnym wzrostowi inteligentnemu jest podporządkowany nie tylko, przywoływany tu, program „Unia Innowacji” (punkt 3. opracowania), ale także dwa pozostałe, tj. „Młodzież w drodze” oraz „Społeczeństwo Cyfrowe” poprzez poprawę edukacji i cyfryzację gospodarki. Wszystkie one są kompatybilne ze soba, jak również z krajowymi strategiami rozwojowymi, aby osiagnać wyzwania smart specialisation. Inteligentna specjalizacja nie jest zupełną nowością, stanowi raczej udoskonalenie i poprawę istniejącej metodologii planowania funduszy strukturalnych i polityki spójności, służące skutecznemu uwolnieniu wewnętrznego potencjału regionów europejskich w kierunku ich innowacyjnego rozwoju. 


\section{Literatura}

Barca F. 2011 Agenda for a Reformed Cohesion Policy, Luksemburg.

Bartkowiak R. 2003 Historia myśli ekonomicznej, Polskie Wydawnictwo Ekonomiczne, Warszawa.

Dahlstrom K., P., Ekins, Nature of the 4 Capitals Model, dokument elektroniczny, tryb dostępu: [www.srdtools.info, data wejścia: 24.04.2013].

Dokument elektroniczny, tryb dostępu: [http://esw-tur.eu/, data wejścia: 24.04.2013].

Dokument elektroniczny, tryb dostępu: [http://www.karpacki.pl/stowarzyszeniekarpaty/projekty-wlasne/polonia-ukraina-transcarpathia-nowe-otwarcie/, data wejścia: 24.04.2013].

Domański R. 2002 Gospodarka przestrzenna, Wydawnictwo Naukowe PWN, Warszawa.

Florida R. 2005 Toward the Learning Regions, Futures, vol. 27.

Greta M. 2003 Euroregiony a integracja europejska. Wnioski dla Polski, Wydawnictwo Uniwersytetu Lódzkiego, Łódź.

Komisja Europejska. Polityka spójności na lata 2014-2020. Strategie badawcze i innowacyjne na ržecz inteligentnej specjalizacji, dokument elektroniczny, tryb dostępu: [www.ec.europa.eu, data wejścia: 7.10.2012].

Kudłacz T. 2001 Programowanie rozwoju regionalnego, Wydawnictwo Naukowe PWN, Warszawa.

Krugman P. R. 1995 Development Geography and Economic Theory, MIT Press, CambridgeLondon.

Krugman P. R. 1991 Geography and Trade, MIT Press-Leuven University Press, London - Leuven.

Molle W. 2011 The Economics of European Integration. Theory, practice, Policy, The Fourth Edition, University Press, Cambridge.

Nowińska-Laźniewska E. 2004 Relacje przestræenne w Polsce w okeresie transformacji w świethe teorii rozwoju regionalnego, Prace habilitacyjne Akademii Ekonomicznej w Poznaniu, Poznań.

Okresowe Raporty na temat społecznej i ekonomicznej sytuacij oraz roz̧woju regionów Unii Europejskiej.

Pietrzyk I. 2001 Polityka regionalna Unii Europejskiej i regiony w państwach czlonkowskich, Wydawnictwo Naukowe PWN, Warszawa.

Regionomica Europe Consulting - Regional Affairs and Business Consultants Dusseldorf/Berlin, dokument elektroniczny, tryb dostępu: [www.karpacki.pl, data wejścia: 24.04.2013]. 